\title{
Arctic Marine Phototrophic Systems: Functions of Sea Ice Stabilization
}

\section{S. APOLLONIO'}

\begin{abstract}
A forgotten nineteenth-century report provides evidence that there are two floras, not one, on the bottom of arctic sea ice, distinguishable in time, species composition, and, perhaps, nutrient condition. A halocline flora is also noted from recent studies that is analogous in habitat to the ice floras. Thus at least three separate autotrophic systems augment phytoplankton production in arctic seas. These augmenting systems seem to be a function of stability provided by sea ice.
\end{abstract}

Key words: sea ice, ice algae, phytoplankton, halocline flora, ecosystem stability

RÉSUMÉ. Un rapport oublié du $19^{e}$ siècle fournit la preuve qu'il existe deux flores, et non pas un seule, au-dessous de la glace marine arctique, et que les deux peuvent être distingués quant à leur âge, leur composition par espèces et parfois, leur condition nutritive. Une flore halocline dont l'habitat est analogue à la flore glaciale est aussi signalée à partir d'études récentes. Donc, au moins trois systèmes autotrophes distincts augmentent la production de phytoplancton dans les mers arctiques. Ces systèmes en pleine croissance semblent résulter de la stabilité assurée par la glace marine.

Mots clés: glace marine, algue marine, phytoplancton, flore halocline, stabilité de l'écosystème

Traduit pour le journal par Maurice Guibord.

Microalgae in polar sea ice have attracted attention in the last 20 years with the publication of reports by Canadian, Russian, Japanese, and American researchers on algal species composition, abundance and productivity, adaptations, and trophic significance within the polar ecosystems. Grainger (1977) and Horner (1977) have reviewed these contributions; both noted that ice biota - "one of the most remarkable phenomena in the sea-ice region" (Hoshiai, 1977) - also attracted attention in the nineteenth and early twentieth centuries and that those earlier reports were primarily taxonomic lists from numerous locations, in contrast to the quantitative and analytic work of recent years. Horner's review concludes with a statement of outstanding unanswered questions concerning these algae, prominent in the list being their origin and their fate when they leave the ice.

One of the purposes of this note is to bring attention to a mid-nineteenth-century contribution that has been completely overlooked in the revival of interest in this phenomenon. It shows that the early observers did not confine their attentions to taxonomic lists only and leads us to consider the implications of that early work in the context of Horner's unanswered questions and for future research on ice flora. This in turn provides an opportunity to point out that there are multiple (probably at least four) photosynthetic production systems in arctic seas and that future work must encompass all of them if we are to understand the functioning of that ecosystem.

The nineteenth-century report to which I refer was written by the Scottish surgeon and naturalist Peter Sutherland, a student and friend of G. Dickie, professor of Natural History at Queen's College, Belfast. Sutherland made four voyages to the Arctic, the first two on the whaler Advice (Captain William Penny) in the late 1840s, the third in the company of Captain Penny on the Lady Franklin and Sophia in 1850-51 in search of Sir John Franklin, and the fourth with Captain Edward In- glefield on the Isabel in the summer of 1852, also as part of the Franklin search efforts. Thus he had much experience with arctic phenomena and he was a careful reporter of many of them. Sutherland (1852) wrote a two-volume (1100 page) account of the 1850-51 voyage. The account attained such size because he included fascinating reports on every conceivable natural phenomenon accessible to his study, in addition to a detailed narrative of the voyage itself. At Dickie's specific request, Sutherland made collections of and notes on ice flora, but the length and detail of Sutherland's journal, as well as its scarcity, may be the reason that all recent reviewers of nineteenth-century work on ice biota have overlooked his observations. Further, tucked among a number of lengthy appendices in his second volume is a report by Dickie (1852) on Sutherland's collections of ice algae. Dickie's and Sutherland's reports may thus be the second contribution to this arctic literature, preceded only by Ehrenburg $(1841$, as cited by Horner, 1977). Sutherland's observations clearly predate Nansen's references (Horner, 1977) to organisms other than diatoms being found in sea ice, and his notes on the massive mucilaginous accumulations of Melosira arctica predate Usachev's (1949).

Sutherland's and Dickie's reports are relevant to current research. Because they are rare and hard to obtain, because Sutherland's ice biota observations are scattered through a voluminous and discursive narrative and have been overlooked, and because they provide an abundance of implications and food for thought, I present in their entirety in the Appendix all those remarks by Sutherland on the phenomenon, as well as the pertinent parts of Dickie's report.

The following few critical notes from Sutherland (found in full in the Appendix) give the basis for the discussion and inferences of the present paper. These observations were made as Sutherland's vessel, Sophia, was attempting to sail north 
through broken and drifting but dense pack ice on the west coast of Greenland north of Disko Island. On 12 May Sutherland remarked that ". . . the weather was very mild and pleasant during the greatest part of the week. The temperature had been rising gradually, and it was up to $+34^{\circ}$ and $+36^{\circ} \ldots$,", temperatures clearly indicative of melting snow and thawing ice.

\begin{abstract}
May 24th.-The ice which had been turned up during the recent pressure was observed to have a number of small cavities... on its under surface. Each cavity contained a greenish, slimy-looking substance...its composition.... a mass of infusory animalcules, and microscopic vegetable forms...

May 30th. -...Wherever the ice had been very much decayed, a dirty brownish slimy substance was observed. . . amongst it; . . A beautiful sieve-like Diatoma was very abundent; ... and when the ice disappears for the season, the brown slimy substance... retires from the surface, and ultimately sinks completely out of view, having never tinged the water in the slightest degree....

July 2 nd. . . . patches of much decayed ice... were dirty, and abounded in the brown slime,...

July 5th.-... The sea around us abounded in a brownish slime... resembling thin mucilage... it was found to be composed chiefly of filamentous algae (Meloseira) [sic] and animalcules...
\end{abstract}

The following note is from Dickie's report:

Melosira arcticum n.s....Dr. Sutherland describes it as...communicating a brown tinge to the water in Melville Bay ... in shreds of mucilaginous consistence....

It is now well recognized that arctic ice flora and phytoplankton are separate autotrophic systems. Apollonio (1961), Clasby et al. (1973), and Horner (1977) have shown that arctic ice flora and phytoplankton blooms are floristically, spatially, and temporally distinct; thus there are at least two systems contributing to arctic marine productivity, rather than one being simply an extension of the other. It is clear that primary production in arctic seas is not dependent solely upon phytoplankton (or upon attached benthic macroalgae in shallow waters). Horner and Schrader (1982) estimated that ice algae provided about two-thirds and the phytoplankton one-third of the spring primary production off Alaska. (But see also Matheke and Horner, 1974, for different estimates of relative contributions.)

One purpose of this paper is to point to the probability that there is a second arctic ice flora, not heretofore recognized as such, separated in time, at least, and possibly also floristically and ecologically distinguishable from that ice flora that has received so much recent attention. Recognition of this probability is tied to recognition of differing states of sea ice. Grainger (1977) first noted that there is an important distinction to be made between mainly drifting ice and largely stable first-year unbroken ice, but recent studies of the now wellrecognized ice algae have overlooked several important points, as noted below, and the important distinction called for by Grainger has not been made.

Recent studies (Apollonio, 1961, 1965; Horner and Alexander, 1972; Grainger, 1977; Hsiao, 1980) have looked at un- broken, snow-covered, fast ice. Each has reported in situ growth of ice algae under snow cover and its subsequent decline and disappearance as the snow melted. Apollonio (1961) also found that artificial snow removal reduced the chlorophyll content of sea ice, from $89.6 \mu \mathrm{g} \cdot 1^{-1}$ to 16.6 $\mu \mathrm{g} \cdot 1^{-1}$. (I have a transparency of the colorless bottom of an ice core that had lost its chlorophyll content after artificial removal of the snow cover, which contrasts clearly with the chlorophyll-colored bottom of an adjacent undisturbed, snowcovered ice core.) Thus these studies demonstrate the termination of the cycle of plant development and decline in intact, unnavigable ice as the snow melts and ice deteriorates with the onset of summer. (The observations of Meguro et al. [1967] off Alaska seem to be a variation or exception to this cycle in that they found an abundant pennate diatom flora in July and August under ice from which "...ablation of the snow cover... was complete....")

But the nineteenth-century reports of ice algae (Grainger, 1977; Sutherland, 1852) are from ships sailing in broken, drifting ice from which snow had disappeared and which had suffered surface melt. I have spent hours and days in late summer - September - on an ice breaker on the east coast of Baffin Island in such conditions watching polar cod stream off the deeply colored undersides of ice floes upended or overturned by the passage of a ship. This is a common experience, frequently observed (Bursa, 1961). But the coloration of those floes cannot be reconciled readily with the documented observations cited above that such color disappears from unbroken ice in the spring as the snow disappears and the ice surface begins to melt. The conclusion seems to follow that there must be a second algal growth on the ice, a growth documented by nineteenth-century reports coming from ships navigating the ice but so far overlooked by twentieth-century research on intact ice; a second growth that is characteristic of "summer ice"' (snow-free, broken, drifting, partially melting) as distinct from 'spring ice"' (snow-covered, intact, not melted).

Fortunately, Sutherland allows us to characterize, to a degree, this "summer ice" algal growth as an abundant brown (not green) mucilaginous slime on the ice or drifting in close proximity to the ice. We have had no advance in our knowledge of this "summer ice" flora since Sutherland's (1852) report, but there is enough in that report to make it clear that this "summer ice" flora may be as distinct from the "spring ice" flora as the latter is from phytoplankton. The apparently high abundance of Melosira spp. (Sutherland, 1852; Usachev, 1949) in this flora is in contrast to the apparent absence of Melosira in fast ice off Alaska (Horner, 1976: Table II), and its low abundance or near-absence in fast ice in the Canadian Arctic (Hsiao, 1980). It is notable also that while the flora of "spring ice" are overwhelmingly pennate diatoms, Melosira spp., a centric diatom, is by far the characteristic diatom found by Sutherland and Dickie in "summer ice." Recent reports of Melosira in "summer ice" include that of Horner (pers. comm.), who observed ". . . huge masses, a meter or more in length..." of $M$. arctica in broken pack ice in late July off Point Barrow, Alaska. Mel'nikov (1980) reported " ... dense colonies..." among the ice of the Arctic Ocean apparently 
late in July. And while we have no nutrient data from "summer ice," it is intriguing that the "mucilaginous" nature of the "summer ice" algae is so prominent. Such a feature appears to be characteristic of nutrient-deficient algae (Miller, 1962; Fisher and Schwarzenbach, 1978) and would reflect a habitat in marked contrast to the nutrient-rich habitat (Apollonio, 1958, 1961; Horner, 1977; Grainger, 1977) in which algae of the "spring ice" flourish. (The ecological or trophic role of this mucilaginous flora is in itself worthy of investigation.) Thus it seems safe to assume that "summer ice" algae are distinct from the "spring ice" flora and in fact form a second ice flora and a third phototrophic system in arctic waters.

In addition to the two ice flora and the phytoplankton, a "halocline" flora has been identified in three arctic locations, meromictic Ogac Lake (lat. $62^{\circ} 52^{\prime} \mathrm{N}$ ) in Frobisher Bay, Baffin Island (McLaren, 1969), and Jones Sound (lat. $75^{\circ} 40^{\prime} \mathrm{N}$ ) and Dumbell Bay (lat. $82^{\circ} 30^{\prime} \mathrm{N}$ ), Ellesmere Island, on the periphery of the Arctic Ocean (Apollonio, 1978, 1980). This system has apparently not been identified or recognized in any other arctic location, but neither has any apparent effort been made to look for it. By its nature, both close-interval depth sampling near the surface and sampling over time are needed to find it, but most of the few arctic phytoplankton studies have lacked that necessary density and frequency of sampling. Undoubtedly it exists in other arctic locations wherever a strong halocline forms and will be found when properly looked for. It is probably a widespread and perhaps a significant component of the arctic marine ecosystem.

This halocline system has the following characteristics: 1) it is located in a narrow vertical depth range within the halocline (at about $2 \mathrm{~m}$ depth) typical of arctic surface waters in the summer; 2) its chlorophyll content seems to be remarkably constant at 1-2 $\mathrm{mg} \mathrm{Chl}_{\mathrm{a}} \cdot \mathrm{m}^{-3}$, as if it were in dynamic equilibrium, perhaps controlled by nutrient diffusion as might be expected at the halocline; 3) it persists for 6-8 weeks, far longer than does the conventional phytoplankton bloom; 4) net ${ }^{14} \mathrm{C}$ production rates are in the range $20-40 \mathrm{mg} \mathrm{C}_{\mathrm{m}}{ }^{-3}$.day. We have no information on the species composition of this flora. There is a suggestion, however, from samples taken elsewhere just under the ice (Bursa, 1963:241) that it is composed of Chlorophyceae and Chrysophyceae. Horner (pers. comm.) suggests this flora may include the euglenoids Dinematomonas litorale, Eutreptiella sp. and Urceolus sp. " . . from seawater in close association with ice...only when ice was present." This halocline composition would be in clear contrast to pennate diatoms, dominant in the "spring ice" biota, and to centric diatoms of the conventional phytoplankton bloom and "summer ice" flora.

The halocline system is associated with arctic sea ice to the extent that the strong density stratification is influenced by the ice, but it is clearly not part of the ice and is therefore not "epontic." Further, if it is dependent upon and constrained by the halocline, neither is it, in the usual sense, "planktonic." A new name would therefore appear to be necessary to characterize this flora.

Dunbar and Acreman (1980) characterized the habitat of sea ice flora as a "ceiling" analogous to the "floor" habitat of benthic flora. This concept is useful for two reasons: it characterizes the habitat of ice flora as both physical and two dimensional, as in fact it is; and the significance of the two arctic ice floras and the halocline flora may be derived from that fact.

Ice floras are significant in that they greatly extend the phototrophic season beyond the very intense but brief bloom of arctic phytoplankton, contributing significantly to total production in the arctic seas. Halocline algae apparently contribute in the same way; they persist in time substantially longer than does the phytoplankton (Apollonio, 1980). It is interesting that these three floras - two ice floras and the halocline flora - depend upon physical structures - the icewater "ceiling" interface and the strong density stratification - for their existence and persistence. Thus the peculiar climatic characteristics of high-latitude arctic seas create a number of physical "compartments" or strata in the ecosystem that support several phototrophic systems, which in aggregate probably substantially extend the duration and enhance the total productivity of the marine ecosystem. It is only the conventional phytoplankton, lacking a physical substrate, which is ephemeral in arctic seas even though astonishing in the exuberance of its growth. Estimates of productivity based solely on phytoplankton may be significant underestimates of total production.

It is of interest also, and probably of significance, that all of the algal systems of arctic seas - ice floras, halocline flora and phytoplankton - are essentially two-dimensional phenomena. All the population and production of each are densely concentrated in very narrow depth strata. Even the phytoplankton production from high latitudes (Apollonio, 1980; unpublished data from Jones Sound, N.W.T., lat. $76^{\circ} 40^{\prime} \mathrm{N}, 1961-63$ ) is strikingly concentrated in a very narrow stratum (1-2 m) of the water column. The significance and implications of this two-dimensional nature of arctic marine phototrophs is worthy of serious thought. It may very well control the species composition and abundance as well as the nature of the faunal communities associated with each flora.

Whereas the role of sea ice has been viewed, primarily, as reducing light penetration and thus limiting productivity in arctic seas, it is becoming clear that in several ways sea ice imparts varieties of stability to the system (Dunbar, 1968) that may more than compensate for reduced light. There are dimensions to the ecological role of sea ice yet to be defined or explored.

\section{ACKNOWLEDGEMENTS}

I wish to thank Drs. R.R.L. Guillard, Rita Horner, and E.H. Grainger for their suggestions for notable improvements to this paper.

\section{APPENDIX}

This appendix contains in their entirety all references to sea ice flora by Sutherland (1852), as well as most of the section on Diatomacea by Dickie (1852), which is largely concerned with samples taken in close association with sea ice. 
May 24th.-The ice, which had been turned up during the recent pressure, was observed to have a number of small cavities, from two to six inches deep, on its under surface. Each cavity contained a greenish slimy-looking substance, which, after two or three days' exposure to the air, gave out a fetid smell. It did not present any definite form of structure to the naked eye, or even to a pocket lens; but there is little doubt that a good microscope would have discovered its composition to be a mass of infusory animalcules, and microscopic vegetable forms; in all probability, Polygasticae and Diatomaceae, and perhaps, also, Confervae. The vital action going on in such masses, in close contact with the under surface of the ice, would maintain a temperature a little above the surrounding medium, which would easily produce the small cavities that attracted our notice. I do not confound these depressions with the innumerable perforations in honeycombed or rotten ice. The surface of each of these was quite smooth, whereas in rotten ice, or ice pitted on the surface from the action of the water alone, it is peculiarly rough.

May 30th.-... Wherever the ice had been very much decayed, a dirty brownish, slimy substance was observed, floating in loose flocculi amongst it, in the surface of the water. The naked eye could detect in it no structure whatever; but on viewing a drop of it through a microscope which magnified about two hundred and fifty diameters, it was found teeming with animal life, and minute vegetable forms of very great beauty. Now would have been the time to perpetuate them with the pencil and the chalk; but unfortunately I could only consign them to the bottle, with the expectation that their delicate siliceous shells would retain their forms until our arrival in England. No one can conceive the vast numbers of these infusorial animalcules in the Polar Seas. Varying in size from $1 / 500$ to $1 / 1000$ of an inch, a single cubic inch will contain perhaps four or five hundred millions of individuals, each furnished with perfect instruments or progression. In some of them 1 could see the cilia in rapid motion, while, to use the words of Professor Jones, "they were swimming about with great activity, avoiding each other as they passed in their rapid dance, and evidently directing their motions with wonderful precision and accuracy" [A General Outline of the Animal Kingdom, by T.R. Jones, F.Z.S., 1841]. In others, no cilia could be detected; but as they, too, were seen in motion, although not so often as the others, there is no doubt that they also possess similar delicately-constituted organs. A beautiful sieve-like Diatoma was very abundant; but the shells which are siliceous were broken very readily. They resemble the Coscinodiscus minor of Kutzing [Kutzing on the Diatomaceae, p. 131, Table I., Figs. x. xi. and xii].

I do not think that these infusoria can be included in the forms of animal life, described by Captain Scoresby, under the comprehensive genus. Medusa, which is very abundant in the Greenland Seas visited by that most distinguished Arctic voyager; nor does there appear to be the slightest resemblance between them, except that both are of very minute size. He says that the sea is sometimes of an olive-green or grass-green colour. This is not at all peculiar to the still bays in Davis Strait, where the infusoria are so abundant. This phenomenon applies to the sea generally, for many leagues, or even degrees, and is not confined to the surface only; neither is it essential to that condition that there be ice. In Davis Strait, the infusoria are generally found most abundant where there is ice, never extending above a few inches, at most a foot, beneath the water; and when the ice disappears for the season, the brown slimy substance is rolled into rounded pellicles, by the rippling of the water, retires from the surface, and ultimately sinks completely out of view, having never tinged the water in the slightest degree, except when it gave the decaying ice a dirty appearance. It is a well known fact, however, that Entomostraca, Acalephre, and Pteropodous mollusca, in great abundance and of various sizes, from $1 / 30$ or $1 / 40$ of an inch in diameter up to half a foot or more, cannot fail to change the colour of the sea in a remarkable manner.

May 31st._... While we waited here [eight miles west of Proven, Greenland], I had an opportunity of examining with a microscope a brown slimy substance, which was seen coming from underneath the fixed ice with the receding tide. As the free edge of the ice was very irregular from pressure and decay, any substance floating in the surface of the water would necessarily be entangled and detained, if its cohesion were sufficient to resist the force of the water. This could be seen very plainly with every tide, and the shreds and wavy ribands of the brown slime were frequently mistaken for seaweed (Laminaria saccharina), many feet in length, which under those circumstances it so much resembled. In addition to minute siliceous animal forms, and also vegetable organisms which could only be discovered by a high magnifying power, this contained a beautiful moniliform siliceous alga, about 1/500 of an inch in diameter, of which the articulations are one and a quarter times as long as broad, containing green granular matter, which imparts to the whole plant its colour, when examined microscopically.

June 30th. - . . The surface of the water between the islands [Duck Islands, Melville Bayl was as smooth as oil in many parts; but occasionally a light breeze, which passed gently over it, ruffled it a little. There was very little ice in the passage we had to take, and what happened to be near us at any time was opening out, under the influence of the tide, much more rapidly than we could advance in the calm, although "all hands" were towing to the utmost of their strength. The ice was much decayed, and it contained amongst it in great abundance the brown slime to which allusion has been made so frequently since we entered the Strait.

July 2 nd. - . . Some patches of much decayed ice, which had never drifted out of the bay, were passed through. The ice was dirty, and abounded in the brown slime, which has been alluded to so frequently already. A single drop of the slime examined with the microscope presented myriads of infusoria, whose cilia could be detected in rapid motion. There were others almost perfectly motionless, some of which were elliptical (Naviculi); and there were also vegetable forms of exquisite beauty: I could see the round sieve-like diatoma, and the siliceous beautifully beaded Meloseira, arranged like shreds of lace work, were scattered loosely over the field of the microscope.

July 5 th. $-\ldots$ The sea around us abounded in a brownish slime, which, when taken out of the water, possessed a consistence resembling thin mucilage, and did not mix very rapidly with it, even by slight agitation. By the assistance of the microscope, it was found to be composed chiefly of filamentous algae (Meloseira) and animalcules, which differed from any that I had hitherto observed. Their motions were very slow compared with the active motions of the ciliated infusoria, and their structure seemed to be a gelatinous mass without cilia, which became inflected as they crawled slowly among the fronds of the algae. I could not distinguish organs of locomotion. At one time it appeared as if the creatures adhered by one extremity, while the other was drawn up by a contractile process. Had I been able to discover the same thing in several subsequent observations, it would have proved the creatures to be some sort of polyp. The slime also contained polygastric infusoria, which were seen moving in the water, with their cilia in rapid and regular motion. In no part of the Strait did we observe such large entomostraca as in Melville Bay. Some of the individuals which came into my hands measured fully half an inch from the tip of the beak to the extremity of the terminal seta or spines, and not less than an inch from tip to tip of the antennae. Their darting motions, and the graceful forms and attitudes which they assumed after each sudden exertion, afforded agreeable pastime to those who could see such beautiful creatures and bestow a few minutes' attention upon them.

The following brief extracts came from Sutherland's observations on ice algae in the intact year-old ice attached to the south shore of Cornwallis Island in the Canadian archipelago. The observations were made on 19 July 1851, after the snow had melted and the meltwater had drained from the surface of the ice.

The floe was considerably drier than when I crossed it a few days 
before...there was an extensive crack in the ice.... The one side of the crack was the margin of an extensive floe, part of the large sheet that went off a few days previously. The other side was the fixed ice.... Looking into this crack, where it was three to four feet wide, the ice appeared to be at least six or eight feet thick; but the lower half was composed of a kind of soft spongy ice holding in its substance great numbers of small fish (Merlangus polaris), which had become frozen in, and also masses of a whitish substance, which evidently was of a vegetable nature, probably accumulations of Diatomacea, which in their white colour differed very much from any of that family of Algae that I had seen before.

The "whitish substance" would appear to be bleached remains of diatoms, perhaps photooxidized, as suggested by Apollonio (1961) and Clasby et al. (1973). But how do we reconcile this observation with Sutherland's next and final observation of algae in "utmost profusion"'? This dilemma may be found also in recent literature.

It may appear rather a strange process that the ice dissolving so rapidly on the upper surface should be increasing nearly as rapidly on the opposite by a sort of transfer of the same water; and it is so far hypothetical; but there is no other way of accounting for what I observed on the east side of Cape Martyr, on the 19th of July, in a deep and still bay, where the ice was then about eight feet thick, nearly the whole of the lower half being a loose spongy mass, in which scores of small fishes had been caught, cruelly detained, and "starved" to death, and myriads of infusoria and siliceous algae luxuriated in the utmost profusion.

The following extracts from Dickie's (1852) report relate to Sutherland's collections of ice algae. But it is at times somewhat unclear as to which flora Dickie refers in this report.

\section{DIATOMACEAE}

At my request, made previous to the departure of the Expedition, Dr. Sutherland paid special attention to the colouring matters of ice and sea-water; samples of such from different localities were carefully collected and forwarded for my inspection. They were found to consist almost solely of Diatomacea; and in some instances fresh-water forms were detected, though rather sparingly, intermixed with others exclusively marine. This is not surprising when we consider the copious discharges of fresh water from the land, occasioned by the melting of snow and ice during the brief summer.

The contents of the alimentary canal of examples of Leda, Nucula and Crenella dredged in Assistance Bay, consisted of mud in a fine state of division, including also numerous Diatomaces identical with those colouring the ice and the water.

Though not a new fact, it is one of some interest in relation to the existence of animal life in those high latitudes. Where Diatomacea abound, certain Mollusca obtain sure supplies of food; these in turn are the prey of fishes; these last contribute to the support of sea mammalia and birds.

After bestowing considerable pains on this family, still I cannot write with full confidence regarding some of the species. Improvements in high powers of the microscope reveal the necessity of paying greater attention to the minute markings of the surface in addition to mere external form. The recent investigations of the Reverend W. Smith in reference to such characters of British species, show the importance of this, and in some measure detract from the general value of Professor Kutzing's useful work, the only one on the subject to which I have access here.

Some of the forms are certainly new: descriptions of such must be deferred to another time, in order that more careful examination than can be bestowed at present may lead to more matured opinions respecting them.

Many of the species enumerated have also been found in other parts of the world, and this confirms the ideas entertained respecting their wide distribution, and the very general diffusion of these minute organisms....

Grammonema Jurgensii Ag. Upon Desmarestia aculeata, and dredged abundantly in two fathoms, along with myriads of minute crustacea, N. lat. $73^{\circ} 20^{\prime}$, W. long. $57^{\circ} 16^{\prime}$; 18th June 1850 .

Melosira arcticum n.s. Frustules transversely elliptical; central line rather faint

The young frustules are nearly spherical. At first I supposed it to be a variety of $\mathrm{M}$. Borreri; but, on more careful examination, I now agree with Reverend $W$. Smith in believing it to be new.

Dr. Sutherland describes it as mix [?] with the two last, and communicating a brown tinge to the water in Melville Bay, off the Devil's Thumb, in shreds of mucilaginous consistence, and infested with numerous microscopic animals; N. lat. $74^{\circ} 40^{\prime} ; 11$ th July 1850 .

Triceratium striolatum Ehr. Dredged in fifteen fathoms, Union Bay; 3rd September 1850. Plentiful, and unmixed with any other Diatomacea.

Fragilaria __ ? This is probably a new species; but at present I cannot venture to write more confidently respecting it. "Taken from the sea-water, when there was no ice, in the form of rounded pellicles of a brown colour, near the eastern extremity of an island, in N. lat. $73^{\circ} 20^{\prime}$, W. long. $57^{\circ} 16^{\prime \prime}$,

The matter deposited from the water in which the Kallymenia already mentioned had been macerated, was found, on careful examination, to contain the following species; some of these are freshwater forms, but they were less abundant than the marine.

\section{Amphora hyalina $\mathrm{Kg}$. \\ Cocconeis borealis $E h r$. \\ Coscinodiscus striatus $\mathrm{Kg}$. minor Ehr. subtilis Ehr.}

And another of the same genus, probably new.

Cyclotella new species.

Cymbella Helvetica $\mathrm{Kg}$

Epithemia Zebra $\mathrm{Kg}$. Westermanni $\mathrm{Kg}$.

Gomphonema acuminatum Ehr. curvatum $\mathrm{Kg}$, var. marinum.

Grammatophora stricta $E h r$. anguina $E h r$.

Navicula quadrifasciata Ehr.? didyma $E h r$.

Odontella obtusa, $\mathrm{Kg}$. aurita $\mathrm{Kg}$.

Rhabdonema minutum $\mathrm{Kg}$.?

Stauroneis aspera $K g$.

Synedra curvula $K g$.? pulchella $\mathrm{Sm}$.

Triceratium striolatum $E h r$.

The following additional species were detected by the Reverend W. Smith:-

\section{Pleurosigma prolongatum $\mathrm{Sm}$. elongatum Sm Fasciola $\mathrm{Sm}$.}

The following species were procured from the washings of Desmarestia aculeata and Chaetopteris plumosa, dredged in $\mathrm{N}$. lat. $73^{\circ} 20^{\prime}$, W. long. $57^{\circ} 20^{\prime}$.

\author{
Cyclotella, new species? already mentioned \\ Cymbella Helvetica. \\ Grammatophora anguina. \\ Navicula didyma. \\ Odontella obtusa. \\ Rhabdonema minutum. \\ Stauroneis aspera. \\ Synedra pulchella. \\ Triceratium striolatum.
}

All these are mentioned above as found in Assistance Bay. 
The washings of Agarum Turneri, from Union Bay, yielded eight species identical with those already noticed as found in Assistance Bay, viz.:

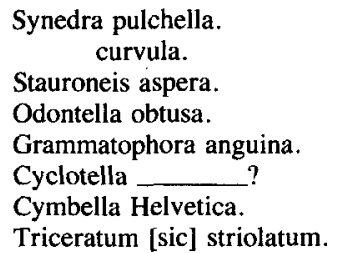

On 29th May, 1850 , in N. lat. $72^{\circ} 15^{\prime}$, Dr. Sutherland states that "A slimy substance was found on the surface of the water and beneath the ice, which was generally decayed and rotten, very abundant in Davis' Straits along the eastern shore, but especially in deep bays where the water is still. When violent pressure happens among the ice, the broken-up floes reduced to the condition of pack ice have a dirty appearance from the presence of this substance." The following species were detected.

\section{Grammonema Jurgensii $\boldsymbol{A g}$. \\ Pleurosigma Thuringica $\mathrm{Kg}$. Fasciola. \\ Navicula, new species? \\ Surirella, new species? \\ Triceratium striolatum.}

A substance very similar to the last, but with a frothy appearance, was collected on 8 th June, 1850 , N. lat. $73^{\circ} 17^{\prime}$; it contained the following: the tissue of all the species was of excessive tenuity:

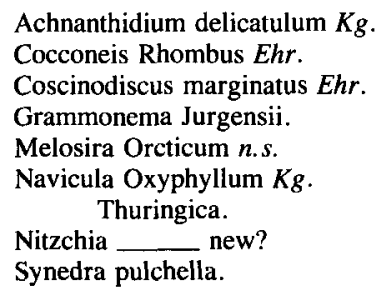

Among rotten ice in N. lat. $73^{\circ} 40^{\prime}$, W. long. $57^{\circ}$, in July, 1851 , a flocculent substance was collected: I found it to consist of the following five species: -

\section{Denticula obtusa $\mathrm{Kg}$ ? \\ Melosira arcticum. \\ Navicula Oxyphyllum. \\ Pleurosigma Fasciola. angulatum $S m$.}

“On 2nd July, 1850, in Hinkson's Bay, N. lat. $73^{\circ} 50^{\prime}$, W. long. $57^{\circ}$, to the southward of Sugar-loaf Hill, a substance scarcely slimy was collected in great abundance, water still, ice very rotten, decaying where it had formed without drifting, the colour brown, sometimes white, and resembling an oily film on the surface of the calm sea."

It contains the following species, all remarkable for the tenuity of their tissue, and most of them destroyed by the action of nitric acid; the Dictyocha, Melosira, Triceratium, and two or three others alone resisting it.

\section{Amphora hyalina.}

Amphiprora alata $\mathrm{Kg}$.

Ceratoneis closterium Ehr.

Cocconeis Rhombus.

Denticula obtusa

Dictyocha gracilis $\mathrm{Kg}$.

Grammonema Jurgensii.

Melosira arcticum.

Navicula Oxyphyllum.

Nitzschia, new species?

Pleurosigma Fasciola. Thuringica.

Schizonema, new species, in fragments.

Triceratium striolatum
In lat. $75^{\circ} 42^{\prime}$, May, 1850 , a matter taken from the surface of the hummocky ice along the beach, in one or two fathoms water, was found to contain the following species:

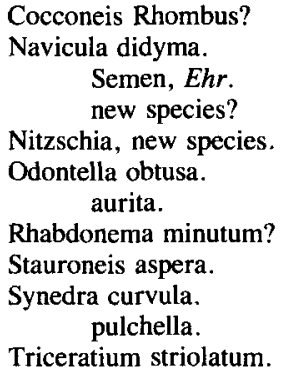

It may be worthy of remark here, that the colouring matter of ice in the Arctic regions sometimes consists of the remains of Algae either in a state of decomposition, or reduced to a pulp by the abrading action of drifting bergs, \&c.; such at least was the nature of specimens examined by me several years ago.

In conclusion, it may be observed how few species there are of the olive-coloured and red Algae; such as are recorded may be considered as fairly representing these plants in the parts visited by the Expedition. The number of littoral species in such regions must be few, or in many places altogether absent; the continual abrading influence of bergs and pack ice would effectually prevent their growth.

In the thinning out of Algae in such latitudes, it is a point of interest to ascertain what genera and species resist longest the influence of conditions inimical to the development of vegetable organisms. Only five of the olive-coloured series are recorded here, four of which are British; the fifth, viz. the Agarum, being exclusively an American form. Of the red series there are only three: one of them, the Polysiphonia, being a common species in Britain; the Dumontia is an American form, the third new.

The green Algae are better represented, six being marine, and fourteen from fresh water or moist places on land, confirming the opinions entertained respecting the more general diffusion of the green than of the olive and red. Of the twenty enumerated, about a third are British.

Of Desmidiea only three were detected in Dr. Sutherland's collection, two of which are British; and the Arthrodesmus has been found in France and Germany.

The Diatomacea, as might have been expected, are numerous. Their importance in reference to the existence of animal life in high latitudes has been already alluded to; and importance out of proportion to their size, the generality of them being so minute that their presence can only be detected by the microscope; or rather it may be remarked that their minuteness renders them important, since they are readily conveyed to the digestive organs of mollusca by currents produced by the numerous cilia on the mantle and gills of these animals. By a wise arrangement, their numbers compensate for their small size. The climate is so unfavourable, that gigantic Algae, such as occur in more favoured regions, cannot exist; the organisms in question, the representatives of the individual cells of which the larger species are composed, supply their place; and the silicious matter which they have the power of separating from the medium in which they live, renders them better fitted to resist the injuries to which they are exposed.

\section{REFERENCES}

APOLLONIO, S. 1958. Hydrobiological measurements on T-3, 1957-1958. Woods Hole Oceanographic Institution. Unpub. ms. 7 p. (Available from Department of Marine Resources, Augusta, Maine.)

1961. The chlorophyll content of arctic sea-ice. Arctic 14:197-200. 1965. Chlorophyll in arctic sea-ice. Arctic 18:118-22. 
1978. Primary production in the Canadian Arctic Archipelago, 1961-1963. Unpub. ms. 62 p. (Available from Department of Marine Resources, Augusta, Maine.)

1980. Primary production in Dumbell Bay in the Arctic Ocean. Marine Biology 61(1):41-51.

BURSA, A. 1961. Phytoplankton of the Calanus expeditions in Hudson Bay, 1953 and 1954. Journal of the Fisheries Research Board of Canada 18(1):51-83.

1963. Phytoplankton in coastal waters of the Arctic Ocean at Point Barrow, Alaska. Arctic 16(4):239-262.

CLASBY, R.C., HORNER, R., and ALEXANDER, V. 1973. An in situ method for measuring primary productivity of arctic sea ice algae. Journal of the Fisheries Research Board of Canada 30(6):835-838.

DICKIE, G. 1852. Notes on the algae. In: Sutherland, P.C. Journal of a voyage in Baffin's Bay... in search of...H.M. ships Erebus and Terror London: Longman, Brown, Green and Longmans. Vol. 2. cxci-cc.

DUNBAR, M.J. 1968. Ecological Development in Polar Regions: a Study in Evolution. Englewood Cliffs, New Jersey: Prentice Hall. viii +118 p.

and ACREMAN, J.C. 1980. Standing crops and species composition of diatoms in sea ice from Robeson Channel to the Gulf of St. Lawrence. Ophelia 19:61-72.

FISHER, N.S., and SCHWARZENBACH, R.P. 1978. Fatty acid dynamics in Thlassiosira pseudonna (Bacillariophyceae): implications for physiological ecology. Journal of Phycology 14(2):143-150.

GRAINGER, E.H. 1977. The annual nutrient cycle in sea ice. In: Dunbar, M.J., ed. Polar Oceans. Proceedings SCOR/SCAR Polar Oceans Conference, Montreal, May 1974. Calgary, Alberta: The Arctic Institute of North America. 285-299.

HORNER, R.A. 1976. Sea ice organisms. In: Barnes, H., ed. Oceanography and Marine Biology, An Annual Review 14:167-182.

1977. History and recent advances in the study of ice biota. In: Dunbar, M.J., ed. Polar Oceans. Proceedings SCOR/SCAR Polar Oceans Conference, Montreal, May 1974. Calgary, Alberta: The Arctic Institute of North America. 269-283.

and ALEXANDER, V. 1972. Algal populations in Arctic sea ice: an investigation of heterotrophy. Limnology and Oceanography 17:454-458.
HORNER, R.A., and SCHRADER, G.C. 1982. Relative contributions of ice algae, phytoplankton, and benthic microalgae to primary production in nearshore regions of the Beaufort Sea. Arctic 35:485-503.

HOSHIAl, T. 1977. Seasonal change of ice communities in the sea ice near Syowa Station, Antarctica. In: Dunbar, M.J., ed. Polar Oceans. Proceedings SCOR/SCAR Polar Oceans Conference, Montreal, May 1974. Calgary, Alberta: The Arctic Institute of North America. 307-317.

HSIAO, S.I.C. 1980. Quantitative composition, distribution, community structure and standing stock of sea ice microalgae in the Canadian Arctic Arctic 33(4):768-793.

MATHEKE, G.E.M., and HORNER, R. 1974. Primary productivity of the benthic microalgae in the Chukchi Sea near Barrow, Alaska. Journal of the Fisheries Research Board of Canada 31:1779-1786.

McLAREN, I.A. 1969. Primary production and nutrients in Ogac Lake, a landlocked fiord on Baffin Island. Journal of the Fisheries Research Board of Canada 26(6):1561-1576.

MEGURO, H., ITO, K., and FUKUSHIMA, H. 1967. Ice flora (bottom type): a mechanism of primary production in polar seas and the growth of diatoms in sea ice. Arctic 20(2):114-133.

MEL'NIKOV, I.A. 1980. The ecosystem of arctic pack ice. Biologiya Tsentral'nogo Arkticheskogo basseina. Moscow: Nauka (Press). 61-111. (In Russian. Department of the Secretary of State of Canada. Multilingual Services Division. Translation Bureau No. 1035889.66 p. 1 November 1982. Available from National Research Council of Canada, Canadian In stitute for Scientific and Technical Information, Ottawa.)

MILLER, J.D.A. 1962. Fats and steriods. In: Lewin, R.A., ed. Physiology and biochemistry of algae. New York: Academic Press. 927 p.

SUTHERLAND, P.C. 1852. Journal of a voyage in Baffin's Bay and Barrow Straits, in the years $1850-1851$ performed by H.M. ships "Lady Franklin" and "Sophia", under the command of Mr. William Penny, in search of the missing crews of H.M. ships Erebus and Terror. London: Longman, Brown, Green and Longmans. 2 vols.

USACHEV, P.I. 1949. The microflora of polar ice. Trudy Instituta Okeanologii, Moscow. 3:216-259. (In Russian. Fisheries Research Board of Canada. Translation series \#1305. 93 p. 26 August 1969.) 